J. Perinat. Med. 12 (1984) 319

\section{Cranial ultrasound after forceful midpelvis vacuum extraction at term}

\author{
P. Jeannin, M. Afschrift*, D. Voet*, F. Vandekerckhove**, M. Thiery**, \\ P.Defoort**, R. Derom**
}

Department of Pediatrics, * Unit for Echography, ** Department of Obstetrics, University Hospital, Gent, Belgium

\section{Introduction}

In many units throughout the world, MALMSTRÖM's [1] vacuum extractor (VE) has become the standard device for obstetric extraction. The versatility and effectiveness of this "clever" [2] instrument have long since been proven [3], but some neonatologists continue to worry about possible untoward perinatal effects of the ventouse delivery, more precisely about the risk of inflicting mechanical trauma on endocranial structures. To tackle this problem we used echography to examine the brains and the meninges of a consecutive series of full-term infants of normal gravidas delivered by difficult vacuum extraction.

\section{Subjects and methods}

The 28 neonates included in this study were born at term (mean $\pm \mathrm{SD}: 38.9 \pm 1.2$ weeks) after a medically uneventful pregnancy. Parity ranged from 1 to 4 (mean: 1.3). Labour had been spontaneous or induced. Extractions were performed during the second stage of labour, with the vertex at -2 to +1 station, either electively or on indication, i.e. delay and/or abnormalities of the cardiotocogram. The position of the head at birth was occipito-anterior in 20 cases and the remaining 8 fetuses were born face-to-pubis. No analgesia except continuous epidural analgesia (CLEA) ( $\mathrm{n}=16$ ) was used. A $5 \mathrm{~cm}$-diameter MALMSTRÖM

\section{Curriculum vitae}

PHILIPPE JEANNIN, born in 1954, M.D.1980. Fellow in Pediatrics at the Academic Hospital, State University of Gent, Belgium.

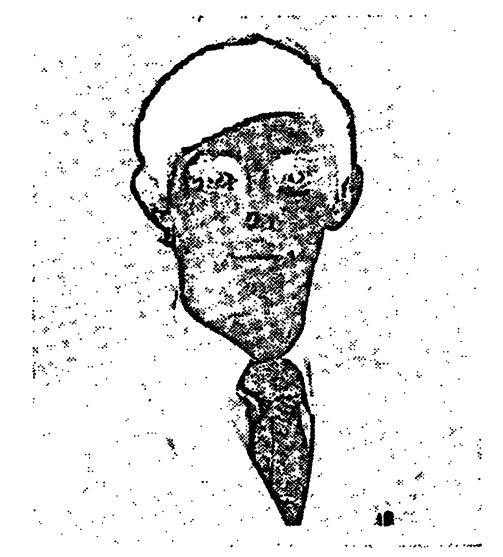

[1] or BIRD [4] cup connected with an automatic vacuum pump was used throughout. The negative pressure $\left(0.8\right.$ to $\left.1.0 \mathrm{~kg} / \mathrm{cm}^{2}\right)$ was created in a single step. Traction was synchronous with uterine contractions, three fingers pushing the cup against the fetal scalp. Arbitrarily, easy VE was defined as a procedure necessitating less than three forceful [5] pulls synchronous with the entire duration of the uterine contraction. The mean \pm SD duration of the second stage of labour was $24.9 \pm 11.0 \mathrm{~min}$. The mean \pm SD interval from application of the cup to delivery was $11.3 \pm 5.7$. The mean \pm SD number of tractions was $6.0 \pm 2.0$. During labour, the uterine activity and fetal heart rate (FHR) pattern were recorded via an intra-amniotic catheter and a scalp electrode, respectively. In order to limit the study to cases in which no fetal distress occurred during the first stage of labour, only those observations were included in which the CTG did not show abnormalities up to the time of 
full dilation. It is the policy of the department to resort to vacuum extraction whenever during the second stage, abnormalities of the CTG are recognized. No detailed description of these is given because except for one or two cases, the umbilicalartery $\mathrm{pH}$ value fell within normal limits and, hence, no significant degree of fetal hypoxia could have been present at the time of extraction. At birth, the infants were examined by the paediatrician and APGAR scores recorded. Within $3 \mathrm{~min}$ of birth, blood samples were taken from the umbilical artery and vein and from the maternal femoral artery for gas and acid-base studies.

Since we wanted to study the effect of the "trauma" caused by the vacuum extraction, the intracranial structures were studied within 72 hours after delivery. The ultrasonography was done with a wideangle $\left(90^{\circ} \mathrm{C}\right)$ mechanical sector scanner (ADRKRANZBÜHLER 4,000 ) with a 3.0 or $5.5 \mathrm{MHz}$ transducer. The scanner was placed on the great fontanel and slowly swept, first from ventral to dorsal, then from left to right, to obtain coronal and parasagittal scans.

\section{Results}

Abrasions of the scalp occurred in 4 babies, and 5 cases of cephalhaematoma were diagnosed.

Tab. I. Abnormal FHR recordings during the second stage.

\begin{aligned} & \hline Case no. Abnormality \\ & \hline 8 progressive bradycardia \\ & 15 terminal bradycardia \\ & 19 transient bradycardia (after CLEA) \\ & 20 persistent bradycardia \\ & 21 persistent bradycardia \\ & \hline\end{aligned}

Abnormal second-stage FHR recordings are shown in Tab. I. Birthweight, APGAR scores, and acidbase values are listed in Tab. II. Fetal-matemal differences in excess lactate fell within normal limits indicating that none of the fetuses suffered from clear-cut hypoxia either before or after the extraction. All echographic findings were normal. One neonate died suddenly on the 3 th day of an unrelated cause. Autopsy showed that the intracranial structures were intact. In the other babies the evolution was uneventful during the first week of life.

\section{Discussion}

Smooth elective VE does not cause fetal hypoxia $[6,7]$ and timely extraction may even have a beneficial effect in terms of the mean decrease of fetal $\mathrm{pH}$ [8]. Although easy elective procedures are not productive of depressed infants, SALING and HARTUNG [9] found that the incidence of low APGAR scores after clinically indicated VE was directly related to the force-time integral of the extraction. Difficult extractions should be defined in terms of power applied to the fetal head. Such measurements are difficult to make in the clinical setting. Admittedly, the criteria we have used, i.e. three or more tractions, can be criticized as being soft, but they allow for a clear-cut entry of cases.

Tedious extractions, especially with (repeated) sudden cup detachment often provoke scalp injury, but damage to deeper cranial structures (subgaleal haematoma, fracture) is exceedingly rare [3]. Intracranial haemorrhage (ICH) has been reported after VE delivery. However, the indication for the procedure and the technique used

Tab. II. Birthweight. APGAR scores, and acid-base and lactate-pyruvate values.

\begin{tabular}{lccc}
\hline & Mean \pm SD & Range & Number of pathologic cases** \\
\hline Birthweight (g) & $3,435 \pm 458$ & 2,340 to 4,500 & $1(<2500)$ \\
5-min APGAR score & $8.0 \pm 1.3$ & 3 to 9 & $1(<7)$ \\
Maternal pH (A.fem.) & $7.41 \pm 0.07$ & 7.26 to 7.58 & $3(<7.32)$ \\
pH umbilical artery & $7.24 \pm 0.05$ & 7.14 to 7.32 & $4(<7.20)$ \\
BE umbilical artery (mEq/l) & $-7.1 \pm 2.7$ & -1.8 to -13.1 & $5(<-10.0)$ \\
$\Delta$ XL $_{\text {f-m }}$ (mEq/1)* & $1.0 \pm 0.7$ & -0.5 to 2.4 & $0(\leqslant 2.6)$ \\
\hline
\end{tabular}

* Fetal-maternal difference in excess lactate

** Definition in parentheses 
seem to play a prominent part in the occurrence of cerebral trauma, and hypoxia further increases the risk of intracranial damage [10]. Although LEIJON [11] found transient neurologic depression to be more frequent in non-asphyxiated VE-delivered neonates, the neurological, psychomotor, psychological and intellectual development of the babies do not seem to be affected by this method of delivery [12] provided it is applied to full-term fetuses and the operative delivery performed correctly, which suggests that the ventouse is indeed the "gentleman's instrument", as CHAMBERLAIN [13] called it. Recently, the heads of VE-delivered infants have been investigated by two new techniques. Computed tomography (CT) showed no correlation between the incidence of $\mathrm{ICH}$ and the mode of delivery $[14,15]$; and there were no cases of vacuum extraction in the series reported by GuEKOS-THöNI et al. [16]. The other technique used for imaging the brain of a newborn infant is ultrasound. Normal brain tissue is mildly echogenic, but strongly echogenic structures are present and allow anatomic identification and the recognitions of lesions. The most prominent echodense structures are the falx cerebri, the chorioideal plexus, tentorium cerebelli, pineal body, part of the pons, and the vermis of the cerebellum. The cerebral ventricles are seen as echo-free slits. Normally, only the lateral ventricles are visualized (Figs. 1 and 2). By far the most frequent echo-

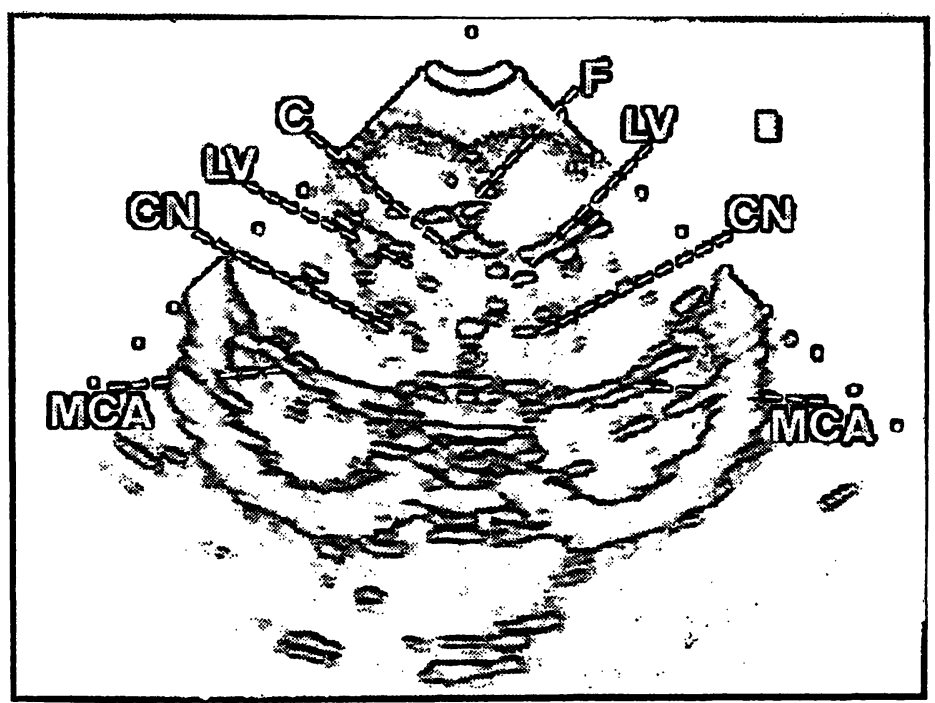

Fig. 1. Coronal cross-section angled to the middle cerebral artery. F: falx; C: corpus callosum; LV: lateral ventricle; $\mathrm{CN}$ : head of caudate nucleus; MCA: Middle cerebral artery:

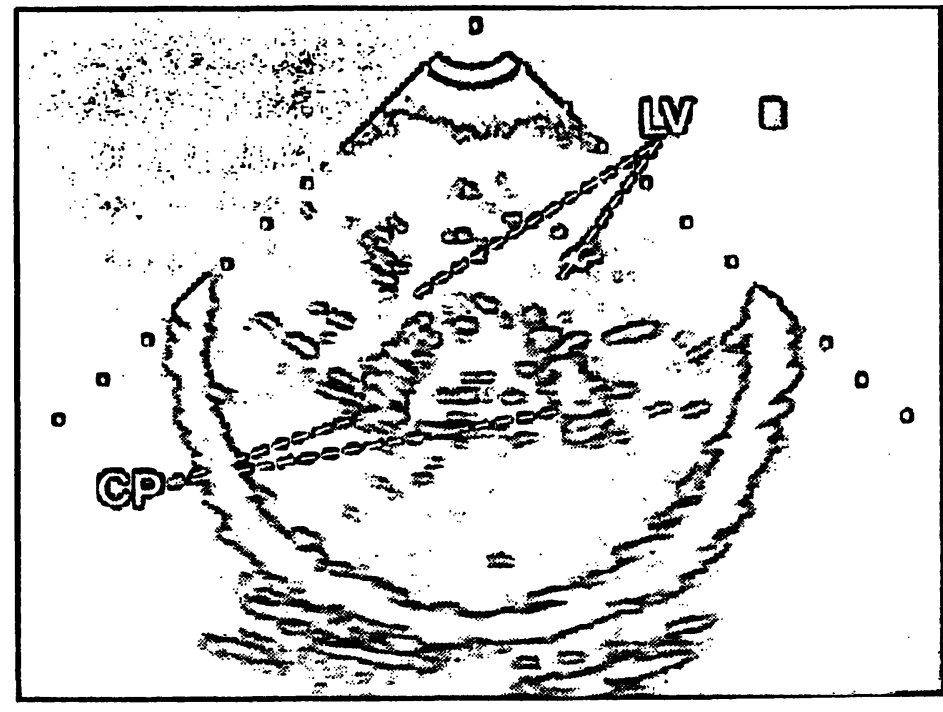

Fig. 2. Coronal cross-section angled posteriorly to the choroid plexus; LV: lateral ventricle; CP: choroid plexus.

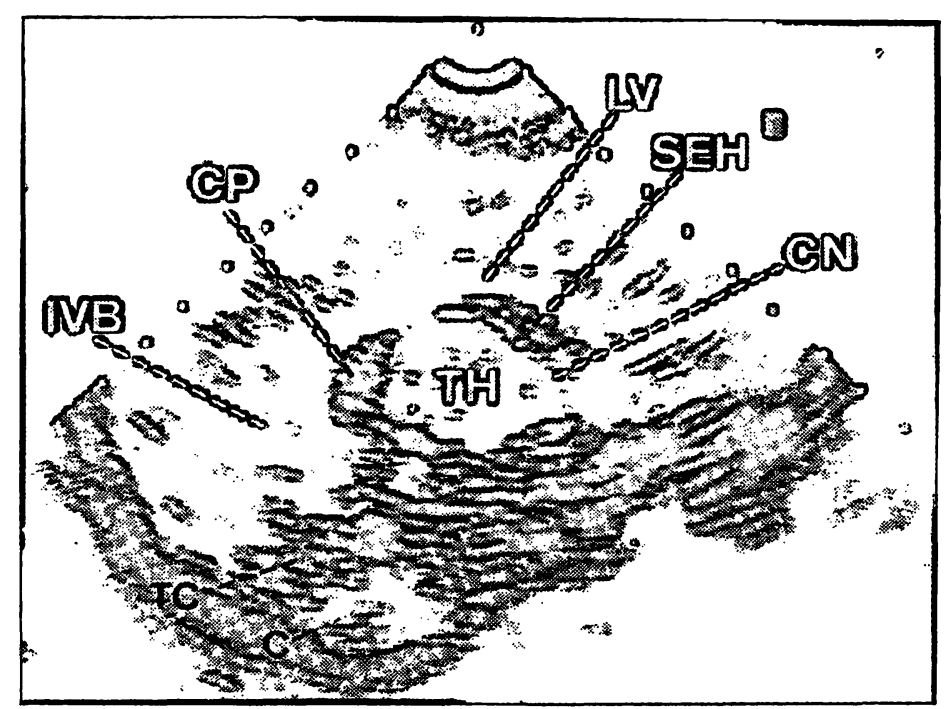

Fig. 3. Angled parasagittal cross section. SEH: subependymal haemorrhage; LV: dilated lateral ventricle; CP: choroid plexus; IVB: intraventricular bleeding; TC: tentorium cerebelli; $\mathrm{C}$ : cerebellum; $\mathrm{TH}$ : thalamus; $\mathrm{CN}$ : caudate nucleus.

dense abnormality is haemorrhage, which usually issues from the subependymal region and may extend into the ventricles or brain tissue (Fig. 3). Thus, ultrasound permits recognition of subependymal, intraventricular, and parenchymal haemorrhage [17] during the early neonatal period (1-3 days). This method has been considered to be as accurate as CT scanning for the diagnosis of $\mathrm{ICH}$, and is much easier to use [18]. Large subdural hematomas can also be visualised with ultrasound. Smaller effusions, however, may escape ultrasonic detection, because the high frontal and 
parietal convexity is difficult to examine. Ultrasound is less helpful in the identification of a subarachnoid hemorrhage [19].

As far as we know, ours it the first systematic study of ultrasound screening in a small series of non-hypoxic VE-delivered infants for ICH to be reported. The results are negative: even after difficult extraction performed because of delay of FHR abnormalities in the second stage of labor in apparen'tly healthy term fetuses, cranial ultrasound did not disclose any cases of ICH or large subdural effusion during the early neonatal period. This conclusion is of practical importance, because this

\section{Summary}

The heads of 28 non-hypoxic, full-term infants of normal gravidas delivered by forceful vacuum extraction were examined with ultrasound during the early neonatal period. All echographic findings were normal and all neonates had an uneventful evolution during the first week of life.

Addendum: Since this article was completed, a massive intracranial haemorrhage occurred in a non-hypoxic full- type of operative delivery, which is accepted everywhere in the world with the exception of the USA, still has fierce critics [20] in spite of the evidence of its innocuity provided by short- and long-term studies. One restriction should be made: as mentioned before, ultrasound does not allow to judge about the occurrence of subarachnoid hemorrhage. This series does not include newborns who had suffered moderate to severe degrees of intra-uterine hypoxia and further investigations will have to be performed to answer the question if VE does not cause of favour ICH in such circumstances.

Key words: Echography, fetal hypoxia, intracranial haemorrhage, scalp injury, vacuum extraction.

\section{Zusammenfassung}

Schädelsonographien nach Vakuumextraktionen von Beckenmitte am Termin

Wir führten bei 28 nicht-hypoxischen Kindern, die nach komplikationsloser Schwangerschaft am Termin durch Vakuumextraktion geboren wurden, in der frühen Neonatalphase eine Schädelsonographie durch. Es wurden ausschließlich Normalbefunde erhoben und alle Neugeborenen waren in der ersten Lebenswoche unauffällig.

Nachtrag: Nach Abschluß der vorliegenden Untersuchung kam es nach einer Vakuumextraktion von Beckenmitte term newborn after elective midpelvic vacuum extraction. The intervention was performed by a resident who, despite the guidelines did not call the senior obstetrician after three unsuccesful attempts to extract the fetus. The head was stationed, $2 \mathrm{~cm}$ above the level of the ischial spines, not completely flexed with the occiput in the right-anterior position. The newborn died at the age of 3 hours. Autopsy showed a tear of the tentorium cerebelli and the vena cerebri magna.

\section{Schlüsselwörter: Fetale Hypoxie, intracranielle Blutung, Skalp-Verletzung, Sonographie, Vakuumextraktion.}

\section{Résumé}

Echographie du crane après extraction énergique à la partie moyenne par ventouse à terme

On a examiné par échographie pendant la période néonatale précoce les têtes de 28 enfants non hypoxiques, à terme après une grossesse normale, extraits par ventouse énergique. Toutes les données échographiques ont été normales et tous les nouveaux-nés ont eu une évolution sans problème au cours de la première semaine de vie.

Addendum: Depuis que cet article a été achevé, une hémorragie intra-cranienne massive est survenue chez un bei einem nicht-hypoxischen Neugeborenen am Termin zu einer massiven intracraniellen Blutung. Die Vakuumextraktion wurde von einem Assistenten durchgeführt, der nicht, wie vorgeschrieben, nach drei erfolglosen Extraktionsversuchen, den Oberarzt hinzurief. Der Kopf stand $2 \mathrm{~cm}$ oberhalb der I-Linie, war nicht vollständig flektiert und das Hinterhaupt führte. Das Neugeborene verstarb nach drei Stunden. Bei der Autopsie sah man einen Riß im Tentorium cerebelli und in der Vena cerebri magna.

Mots-clés: Echographie, hémorragie intra-cranienne, hypoxie fœtale, lésion du scalp, vacuum extractor, ventouse.

nouveau-né à terme, non hypoxique après extraction par ventouse à la partie moyenne. L'intervention a été effectuée par un résident qui en dépit de la règle, n'a pas appelé l'obstétricien après 3 essais infructueux pour extraire le fœtus. La tête était bloquée à $2 \mathrm{~cm}$ au-dessus du niveau des épines, mal fléchie en occipito iliaque droite antérieure. Le nouveau-né est décédé à l'âge de 3 heures. L'autopsie a mis en évidence une déchirure de la tente du cervelet et de la vena cerebra magna. 


\section{Bibliography}

[1] MALMSTRÖM, T.: The vacuum extractor, an obstettrical instrument. Acta Obstet. Gynecol. Scand. 36 (suppl. 3) (1957) 1

[2] DONALD, I.: Practical Obstetric Problems. LloydLuke Ltd, London 1979, p. 667

[3] ChAlmERS, J. A.: The Ventouse. Lloyd-Luke Ltd, London 1971

[4] BIRD, G. C.: Modification of Malmström's vacuum extractor. Br. Med. J. 3 (1969) 526

[5] THIERY, M., H. VAN KETS, R. DEROM: Recording of tractive power in vacuum extraction. J. Perinat. Med. 1 (1973) 291

[6] DEROM, R., M. THIERY, E. LYBEER: The lactatepyruvate balance in relation to vacuum extraction. J. Obstet. Gynaecol. Br. Cwlth. 72 (1965) 892

[7] LIVNAT, E. J., M. FEJGIN, A. SCOMMEGNA et al.: Neonatal acid-base balance in spontaneous and instrumental vaginal deliveries. Am. J. Obstet. Gynecol. 52 (1978) 549

[8] KATZ, Z., M. LANCET, R. DGANI et al.: The beneficial effect of vacuum extraction on the fetus. Acta Obstet. Gynecol. Scand. 61 (1982) 337

[9] SALING, E., M. HARTUNG: Analysis of tractive forces during the application of vacuum extraction. J. Perinat. Med. 1 (1973) 245

[10] PLAUCHÉ, W. C.: Fetal cranial injuries related to delivery with the Malmström vacuum extractor. Obstet. Gynecol. 53 (1979) 750

[11] LEIJON, I.: Neurology and behaviour of newborn infants delivered by vacuum extraction on maternal indication. Acta Pediatr. Scand. 69 (1980) 625

[12] HOHLWEG-MAJERT, P., A.GOYERT, A.SCHMITT: Psychomotorische Entwicklung von operativ geborenen Kindern durch Sectio, Vakuum und Forzeps im Lebensalter von 3-7 Jahren. Z. Geburtshilfe Perinat. 183 (1979) 375

[13] Chamberlain, G.: Pers. Comm., 1982
[14] BROCKERHOFF, P., M.BRAND, B.LUDWIG: Untersuchungen zur Häufigkeit perinataler Hirnblutungen und deren Abhängigkeit vom Geburtsverlauf mit Hilfe der cranialen Computertomographie. Geburtshilfe Frauenheilk. 41 (1981) 597

[15] LUDWIG, B., M. BRAND, P. BROCKERHOFF: Postpartum CT examination of the heads of full term infants. Neuroradiology 20 (1980) 145

[16] GUEKOS-THÖNI, U., E. BOLTSHAUSER, D. MIETH et al.: Intracranial haemorrhage in the term infant confirmed by computed tomography. Helv. Paediatr. Acta 35 (1980) 531

[17] PAPE, K.E., R. J. BLACKWELL, G. GUSICK: Ultrasound detection of brain damage in preterm infants. Lancet 1 (1979) 1261

[18] LEBED, M. R., B. S. SHIFRIN, F. WAFFRAN et al.: Real-time $B$ scanning in the diagnosis of neonatal intracranial hemorrhage. Am. J. Obstet. Gynaecol. 142 (1982) 851

[19] THORNBURN, R. J., A. P. LIPSCOMB, E. O. R. REYNOLDS et al.: Accuracy of imaging of the brains of newborn infants by linear-array real-time ultrasound. Early Hum. Dev. 6 (1982) 31

[20] NEWMAN, C.: Vacuum extraction deliveries. Obstet. Gynecol. 59 (1982) 670

Received November 4, 1983. Revised April 6, 1984. Accepted April 8, 1984.

Dr. Ph. Jeannin

Vrouwenkliniek

Afdeling Verloskunde

Academisch Ziekenhuis

Rijksuniversiteit Gent

De Pintelaan 185

9000-Gent, Belgium 
